\title{
KNOWLEDGE-BASED ECONOMY (KBE), KONVERGENSI, DAN PERTUMBUHAN EKONOMI : STUDI KASUS DI ASEAN PLUS THREE (PERIODE TAHUN 2001-2014)
}

\author{
Zulva Azijah ${ }^{1}$, Muhammad Findi A ${ }^{2}$, Tony $\operatorname{Irawan}^{2}$ \\ ${ }^{1}$ Mahasiswa Magister Program Studi Ilmu Ekonomi, FEM IPB \\ ${ }^{2}$ Staf Pengajar FEM IPB
}

Artikel diterima Agustus 2015

Artikel disetujui untuk dipublikasikan Desember 2015

\begin{abstract}
Economic growth and convergence are the major issues in the global economic. Economic integration is a form of cooperation between countries in order to achieve welfare and prosperity. In 1997, ASEAN Plus Three has been established as an economic integration in the field of innovation and ICT. The aims of this study are to analyze the conditional convergence $(\beta)$ and covergence $(\sigma)$ and to consider the role of Knowledge-Based Economy on economic growth. This study uses annual data from 2001 to 2014 with a GMM approach. The case study of this research are the members of ASEAN Plus Three. The resultsof conditional convergence ( $\beta$ ) estimation showed that the best dynamic panel criteria is not bias, valid dan consistent. The coefficient of conditional convergence $(\beta)$ with $K B E$ indicators that is 0.9917 has convergence rate of $0.8 \%$. On the convergence $(\sigma)$, the result showed that in the period 2001 to 2014, there has been a convergence in real GDP per capita that can be seen from the coefficient variation values that tend to be declined.
\end{abstract}

Keywords: Convergence, Knowledge-Based Economy, Economic Growth, Innovation

\section{PENDAHULUAN}

\section{Latar Belakang}

Era globalisasi telah menciptakan persaingan antarnegara di dunia internasional. Persaingan telah berdampak pada disparitas perekonomian antara negara berkembang dengan negara maju. Pertumbuhan ekonomi dan konvergensi merupakan salah satu indikator ekonomi yang dapat menggambarkan besarnya disparitas atau kesenjangan antarnegara maju dan negara berkembang. Pertumbuhan ekonomi dapat diartikan sebagai kenaikan GDP (Gross Domestic Product) tanpa melihat perubahan pertumbuhan penduduk dan perubahan struktur ekonomi yang terjadi (Arsyad 1997). Sedangkan konvergensi merupakan kondisi yang menggambarkan semakin kecilnya kesenjangan atau disparitas suatu variabel antarwilayah dalam periode tertentu (Dekiawan 2014).

Integrasi ekonomi antarnegara maju dan negara berkembang bertujuan untuk membangun suatu kekuatan ekonomi diantara negara anggota dalam menghadapi persaingan di dunia internasional. Pada tahun 1997 Indonesia melakukan integrasi ekonomi dengan negara ASEAN Plus Three, yang terdiri dari negara ASEAN ditambah negara Cina, Jepang dan Korea Selatan. Salah satu bentuk kerjasama yang 
dilakukan oleh ASEAN Plus Three adalah kerjasama dalam bidang inovasi dan ICT (information communication dan technology) (Kementerian Luar Negeri RI 2011).

Kerjasama inovasi dan ICT dengan segala rangcangan kebijakan diantara Indonesia dengan anggota ASEAN Plus Three merupakan gabungan dari indeks knowledge-based economy (Tocan 2012). Hal tersebut telah memberikan kemudahan baik dalam penemuan barang baru yang selanjutnya dapat dipatenkan ataupun kemudahan untuk mengakses informasi diantara para pelaku ekonomi. Sebagai bentuk kesiapan Indonesia dalam menghadapi kerjasama ASEAN Plus Three, telah dirancang regulasi dan kebijakan internal yang tertuang dalam Pasal 31 ayat 5 UUD Tahun 1945 yang menyatakan bahwa pemerintah memajukan knowledge dengan menjunjung tinggi nilai-nilai agama dan peraturan bangsa untuk memajukan peradaban serta kesejahteraan umat manusia (Kementerian Riset dan Teknologi 2014).

$\begin{array}{rrr}\text { Stiglitz } & (1999) \\ \text { menjelaskan } & \text { bahwa pentingnya }\end{array}$ knowledge tidak hanya untuk memperluas wawasan, tetapi sebagai dasar untuk dapat meningkatkan kemampuan dan keahlian dalam melakukan suatu aktivitas. Hal ini dapat menjadi strategi untuk mencapai pertumbuhan ekonomi yang berkelanjutan di masing-masing negara.

Pasca hampir dua dekade dilaksanakan kerjasama ASEAN Pluss Three namun jika dilihat dari besarnya nilai GDP masih memiliki perbedaan yang cukup besar antara negara maju dengan negara berkembang. Negara dengan GDP riil per kapita tertinggi didominasi oleh negara maju yaitu Singapura, Brunei Darussalam, Jepang dan Korea Selatan secara berurutan sebesar US\$ 38 087.66, US\$ 23 640.8, US\$ 37595.2 dan US\$ 24 565.6. Hal ini dikarenakan adanya kemudahan akses terhadap knowledge-based economy di negara maju seperti Singapura, Jepang, dan Korea Selatan. Sehingga hal tersebut dapat menciptakan produktivitas yang lebih efektif dan efisien.

Lain halnya dengan negara berkembang seperti Brunei Darussalam yang memiliki nilai GDP yang tinggi. Kontribusi terbesar dari penerimaan GDP Brunei Darussalam berasal dari sektor migas. Sedangkan negara berkembang lainnya seperti Malaysia, Thailand, Cina, Indonesia, Filipina, dan Vietnam secara berurutan memiliki GDP riil per kapita sebesar US\$ 7 365.24, US\$ 3 768.79, US\$ 3 862.92, US\$ 1 853.81, US\$ 1 662.07, dan US\$ 1077.92 .

Periode tahun 2010 2014 pertumbuhan ekonomi baik di negara maju dan di negara berkembang mengalami fluktuasi. Negara Singapura yang memiliki nilai $G D P$ riil per kapita paling tinggi, ternyata mengalami pertumbuhan ekonomi yang menurun dari tahun 2013 ke tahun 2014 sebesar $2.76 \%$ menjadi $1.59 \%$. Namun untuk negara berkembang memiliki pertumbuhan GDP per kapita yang cenderung meningkat yaitu Cina, Malaysia, Indonesia, Filipina dan Vietnam dengan persentase pertumbuhan ekonomi mencapai $6.73 \%$, $4.44 \%, 5.98 \%, 4.45 \%$, dan $4.85 \%$ untuk tahun 2014.

Schumpeter (Bhaduri 2007) menyatakan bahwa pertumbuhan ekonomi dan pembangunan dipengaruhi oleh inovasi. Inovasi merupakan bagian dari knowledge-based economy. Hal ini didukung oleh penelitian Karagiannis (2007) yang menyatakan bahwa knowledge-based economy dapat mengatasi fluktuasi ekonomi dan 
menciptakan pertumbuhan ekonomi yang berkelanjutan. European Commmision (2003) menyatakan indikator yang termasuk dalam knowledge-based economy (KBE) diantaranya paten dan pengguna internet.

Knowledge-based economy merupakan sumber terbentuknya inovasi dan ICT sebagai landasan tumbuhnya kreativitas sumberdaya manusia. Saat ini, knowledge-based economy telah memaksa para pelaku ekonomi untuk lebih progresif dan kompetitif. Coates dan Warvick (1998) menjelaskan mengenai pentingnya knowledge-based economy, diantaranya: Pertama, perubahan revolusi dari ICT (Information, Communication, and Technologies) mempengaruhi produktivitas dari masing-masing negara. Kedua, kemajuan dalam bidang ilmiah dan teknologi telah menciptakan peningkatan sumberdaya $R \& D$ baik yang dilakukan oleh pihak perusahaan atau pemerintah. Ketiga, Persaingan dunia global berdampak pada penurunan tarif, liberalisasi kapital, pengurangan transportasi dan biaya transaksi. Keempat, perubahan permintaan dan peningkatan pendapatan berpotensi sebagai pendorong adanya knowledge-based economy.

Pada tahun 2008 dalam penelitian yang dilakukan oleh Ismail dengan tujuan mengkaji isu-isu konvergensi dan pertumbuhan ekonomi di ASEAN. Hasil estimasi menunjukkan bahwa telah terjadi konvergensi di negara ASEAN. Namun, penelitian tersebut belum memasukkan peran dari knowledge-based economy.

Sehingga
menyempurnakan penelitian terdahulu
maka penulis bermaksud untuk
mengkaji secara lebih luas dan
mendalam mengenai knowledge-based

economy (KBE), konvergensi dan pertumbuhan ekonomi dengan studi kasus di negara yang tergabung dalam ASEAN Plus Three. Penelitian ini menggunakan dua indikator utama yaitu paten dan pengguna internet.

\section{Tujuan Penelitian}

Berdasarkan uraian diatas maka tujuan penelitian adalah (1) Menganalisis proses konvergensi di ASEAN Plus Three dengan pendekatan pendapatan perkapita dan KnowledgeBased Economy (KBE). Menganalisis efek Knowledge-Based Economy (KBE) terhadap pertumbuhan ekonomi di ASEAN Plus Three.

\section{TINJAUAN STUDI TERDAHULU}

Powell dan Snellman (2004) mendefinisikan knowledge-based economy sebagai aktivitas produksi dan jasa yang berbasiskan knowledge yang dapat memberikan kontribusi terhadap kemajuan ilmiah. Komponen kunci dari knowledge-based economy adalah mengandalkan kemampuan intelektual dari pada input fisik ataupun sumberdaya alam. Penelitian Karagiannis (2007) menyatakan bahwa knowledge-based economy memiliki peran penting dalam pertumbuhan ekonomi dan konvergensi suatu negara.

$$
\text { Proses konvergensi }
$$

merupakan semakin kecilnya tingkat kesenjangan di wilayah tersebut. Oleh karena itu maka konvergensi penting untuk melihat dan menghitung tingkat kesenjangan perekonomian pada suatu wilayah. Dekiawan (2014) melakukan penelitian mengenai konvergensi penerimaan dan pengeluaran APBD provinsi di Indonesia dengan rentang waktu 2000-2012. Hasil penelitian menunjukkan bahwa pada periode 2000-2012 konvergesi $(\sigma)$ terjadi pada 
variabel PAD (Pendapatan Asli Daerah), pajak, dana perimbangan, total belanja, belanja pegawai dan belanja barang. Sedangkan estimasi dengan pendekatan konvergensi $(\beta)$ menunjukkan konvergen pada variabel $\mathrm{PAD}$, pajak, total belanja dan belanja barang.

Penelitian lain dilakukan oleh Firdaus dan Yusop (2009) dengan hasil analisis menunjukkan bahwa telah terjadi proses konvergensi diantara provinsi-provinsi di Indonesia untuk periode 1983 - 2003. Tingkat konvergensi di Indonesia relatif sangat lambat dibandingkan dengan penelitian lain di negara-negara berkembang dengan nilai sebesar $0.29 \%$. Chen dan Sun (2013) juga melakukan penelitian mengenai konvergensi di negara Cina yang merupakan negara dengan tingkat inovasi dan pertumbuhan ekonomi tinggi dibandingkan dengan negara berkembang lainnya. Hasil penelitian menyatakan bahwa telah terjadi kovergensi absolut (lemah) dan kondisional pada periode 1990-2010.

Selain itu, terdapat penelitian konvergensi yang pada beberapa negara yang lebih luas seperti penelitian yang dilakukan oleh Wibowo (2012) melakukan penelitian mengenai konvergensi di ASEAN+5. Hasil penelitian menunjukkan bahwa perkembangan industri keuangan yang cukup baik terutama di negara berpendapatan tinggi. Financial inclusion berpengaruh positif terhadap pertumbuhan ekonomi. Koefisien dari lag variabel endogen pada model mengindikasikan bahwa telah terjadi konvergensi pertumbuhan ekonomi di negara $A S E A N+5$.

Michelis dan Neaime (2004) juga melakukan penelitian mengenai konvergensi di negara Asia-pacific. Tujuan penelitian untuk mengevaluasi secara empiris mengenai konvergensi pendapatan pada negara yang tergabung dalam APEC, 10 EASTASIA dan 5 ASEAN. Hasil penelitian menujukkan konvergensi $(\beta)$ dan konvergensi $(\sigma)$ yang sejalan.

Sedangkan Young, Higgins dan Levy (2008) melakukan penelitian mengenai konvergensi di U.S dengan hasil penelitian yang menyatakan bahwa konvergensi $(\beta)$ tidak selalu sejalan dengan konvegensi $(\sigma)$. Dibuktikan negara U.S pada periode 1970-1998 terjadi konvergensi $(\beta)$, tetapi dengan data yang sama juga terjadi divergensi $(\sigma)$. Selain itu, tingkat pertumbuhan ekonomi di kabupaten kaya lebih besar dan stabil jika dibandingkan dengan kabupaten miskin di U.S.

\section{METODE PENELITIAN}

\section{Metode Analisis Data}

Data yang digunakan dalam penelitian ini adalah data sekunder yang terdiri dari periode waktu tahun 2001 hingga tahun 2014. Data yang digunakan meliputi 10 negara yang tergabung dalam ASEAN Plus Three, diantaranya: Brunei Darussalam, Jepang, Korea Selatan Malaysia, Thailand, Cina, Indonesia, Filipina dan Vietnam. Sedangkan untuk Negara Myanmar, Kamboja dan Laos tidak dimasukkan ke dalam penelitian dikarenakan keterbatasan data. Struktur data yang digunakan dalam penelitian berupa data panel, yaitu gabungan antara data time series dan cross section. Data-data tersebut diperoleh dari World Development Indicators (WDI) dan International Telecomunications Union (ITU). Peneliti juga menggunakan sumbersumber lain seperti jurnal, artikel serta literatur-literatur lainnya untuk menambah informasi terkait penelitian. 


\section{Model Konvergensi Ekonomi}

Penelitian ini akan mengukur konvergensi $(\beta)$ dan konvergensi $(\sigma)$ di negara-negara ASEAN Plus Three. Model konvergensi dalam penelitian merupakan modifikasi dari model Paas et al. (2007), yang dirumuskan sebagai berikut:

$$
\begin{gathered}
\ln Y_{i t}=b_{0}+b_{1} \ln Y_{i t-1}+b_{2} \ln P O P_{i t}+b_{3} \\
\operatorname{lnTr}_{i t}+b_{4} G F C F_{i t}+b_{5} \text { Gov }_{i t}+ \\
b_{6} \ln P t_{i t}+b_{7} \text { Iuser }_{i t}+v_{i t}
\end{gathered}
$$

Ket:

$$
\begin{aligned}
& Y_{i t}=G D P \text { per kapita pada } \\
& \text { tahun ke } \mathrm{t} \text { (US\$) } \\
& Y_{i t-1}=G D P \text { per kapita tahun } \\
& \text { sebelumnya (US\$) } \\
& P O P=\text { Jumlah populasi (orang) } \\
& \operatorname{Tr} \quad=\text { Perdagangan terhadap } \\
& \text { GDP }(\%) \\
& G F C F=\text { Investasi domestik } \\
& \text { terhadap GDP }(\%) \\
& \text { GovC }=\text { Konsumsi Pemerintah } \\
& \text { (\%) } \\
& \text { Pt } \quad=\text { Paten (orang) } \\
& \text { Iuser }=\text { Pengguna internet }(\text { per } \\
& 100 \text { orang) } \\
& v_{i t} \quad=\quad \text { error } \text { pada periode } \mathrm{t} \\
& i=\text { cross section pada } 10 \\
& \text { negara ASEAN Plus } \\
& \text { Three } \\
& t=\text { time series tahun 2001- } \\
& 2014
\end{aligned}
$$

Konvergensi $(\sigma)$ menggambarkan semakin berkurangnya kesenjangan pendapatan perkapita sepanjang waktu. Analisis konvergensi ( $\sigma$ ) merupakan analisis rutut waktu untuk mengamati terjadinya konvergensi atas variabel pengamatan dilakukan dengan perhitungan koefisien variasi (coefficient of variation), seperti yang dilakukan oleh Lall dan Yilmaz (2001) yang sudah dimodifikasi sebagai berikut

$$
C V=\frac{\sqrt{\frac{\sum\left(\mathrm{Y}_{\mathrm{i}}-\overline{\mathrm{Y}}\right)^{2}}{\mathrm{~N}}}}{\overline{\mathrm{Y}}} \times 100 \%
$$

Dimana $C V$ merupakan coefficient of variation variabel pengamatan. $Y_{i}$ adalah variabel pendapatan per kapita $(G D P)$ negara yang tergabung dalam ASEAN Plus Three. $\bar{Y}$ adalah rata-rata untuk masing-masing variabel pendapatan per kapita (rata-rata $Y$ ). N adalah jumlah negara.

\section{HASIL DAN PEMBAHASAN}

\section{Analisis Knowledge-Based Economy (KBE) di ASEAN Plus Three}

Powell dan Snellman (2004) mendefinisikan knowledge-based economy (KBE) sebagai produksi dan jasa yang berbasiskan pada ilmu pengetahuan yang intensif yang berkontribusi untuk menciptakan teknologi dan sains yang lebih maju dari masa sebelumnya. Pemahaman KBE yang diterapkan pada aktivitas ekonomi akan menghasilkan produk yang berkualitas, dengan proses produksi yang lebih efisien dan efektif.

Stiglitz (1999) menjelaskan bahwa knowledge-based economy menurut sifatnya dibagi kedalam dua klasifikasi, yaitu knowledge bersifat tacit dan explicit. Tacit knowledge merupakan pengetahuan yang berupa pemahaman, skill, pengalaman dan lainlain. Knowledge yang bersifat tacit sulit untuk diukur karena tersimpan pada memori otak setiap manusia sesuai dengan kompetensinya. Sedangkan explicit knowledge adalah komponen knowledge yang dapat dikodekan dan diteruskan kedalam bahasa sistematik dan formal seperti dokumen, database dan sebagainya. tacit dan explicit knowledge dapat ditransfer dan dikonversi sehingga dalam jangka 
panjang akan terjadi perkembangan knowledge yang berkelanjutan.

Penelitian Karagiannis (2007) yang menyatakan bahwa era modern knowledge-based economy merupakan faktor penting pendorong produktivitas dan pertumbuhan ekonomi. World Development Indicators (2012) membagi knowledge-based conomy menjadi empat pilar utama diantaranya :

1. Economic incentive dan institutional incentives dapat menciptakan efisiensi dalam penggunaan knowledge dan mengembangkan jiwa entrepreneurship.

2. Tingkat pendidikan dan skill pada individu dapat membuat penggunaan knowledge menjadi lebih baik

3. Efisiensi inovasi dan teknologi baru pada perusahaan, pusat penelitian, universitas, konsultan, dan berbagai organisasi lainnya sampai pada
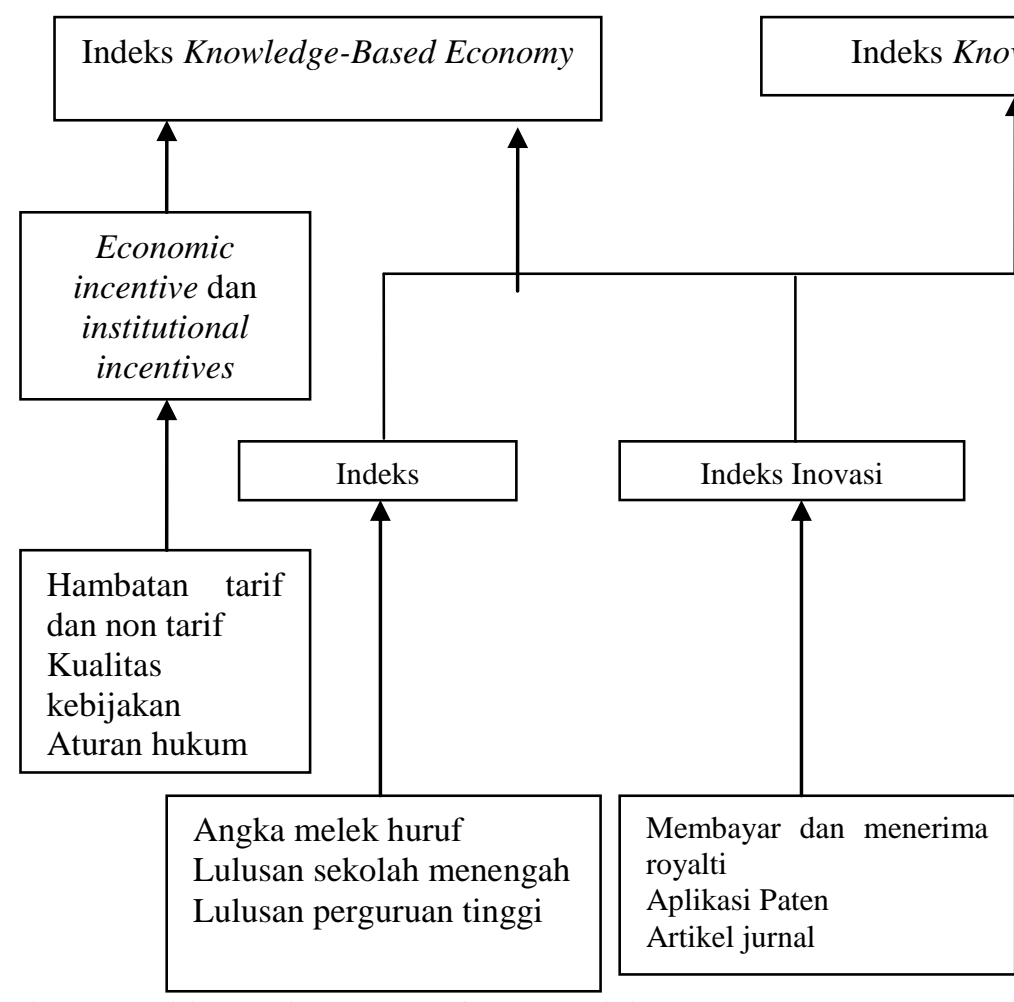

pertumbuhan knowledge di dunia global, digunakan untuk menciptakan teknologi baru yang sesuai dengan kebutuhan lokal.

4. Teknologi informasi dan komunikasi sebagai fasilitas yang efektif dalam menciptakan kreasi dan mendapatkan informasi

Empat pilar dari knowledge-based economy yang diperkuat akan menyebabkan peningkatan pada kuantitas dan kualitas sebagai sumber pengetahuan dalam bidang ekonomi di berbagai negara. Knowledge-based economy juga akan meningkatkan produktvitas dan pertumbuhan ekonomi (Tocan 2012). World Development Indicators (2012) juga telah mengembangkan indeks knowledgebased economy dan indeks knowledge yang digambarkan oleh Gambar 1.

\section{Gambar 1 Indeks Knowledge-Based Economy (KEI) dan Knowledge (KI)}


Berdasarkan Gambar 1 menunjukkan bahwa indeks knowledge merupakan bagian dari indeks knowledge-based economy. Indeks knowledge dibagi menjadi tiga bagian penting, yaitu indeks pendidikan, indeks inovasi dan indeks ICT (Information Communication dan Technology). Sedangkan indeks knowledge-based economy terdiri dari economic incentive dan institutional incentives serta indeks knowledge. Dalam penelitian ini peran knowledge-based economy dilihat dengan pendekatan dari variabel pengguna internet dan variabel paten.

\section{Hasil Estimasi Peran Knowledge Based Economy, Konvergensi, dan Pertumbuhan Ekonomi di ASEAN Plus Three}

\section{Analisis Konvergensi Kondisional ( $\beta$ )}

Pengujian data panel dengan metode Generalized Method of Moment (GMM) memiliki tiga tahap pengujian. Pertama, uji estimasi model tidak bias yang ditunjukkan oleh nilai koefiisien lag dari variabel dependen berada diantara Pooled Least Square (PLS) dan Fixed Effect Model (FEM). Kedua, uji konsistensi model yang dilihat dari hasil uji Arellano-Bond statistik $A R(1)$ menunjukan $H_{0}\left(H_{0}\right.$ : no autocorrelation) ditolak dan $A R(2)$ menunjukkan hipotesis tidak tolak $H_{0} \quad\left(H_{0}\right.$ : no autocorrelation). Ketiga, instrumen valid jika uji Hansen J menunjukan nilai yang lebih besar dari taraf nyata $(1 \%$, $5 \%$, dan $10 \%$ ), sehingga tidak tolak $H_{0}$ ( $H_{0}$ : valid).

Hasil estimasi pada Tabel 1 kolom 4 telah menunjukkan kriteria panel dinamis terbaik. Pada kolom 4 menyatakan hasil estimasi tidak bias karena nilai koefisien pada lag $Y_{i t-1}$ (0.9928) berada diantara FEM dan PLS (0.9639-0.9929). Selain itu, hasil estimasi validitas pada kolom 4 dilihat dari uji Hansen $\mathbf{J}$ menunjukkan tidak signifikan pada taraf nyata $5 \%$ atau belum cukup bukti untuk tolak $H_{0}$, sehingga dapat dikatakan bahwa model tersebut valid. Pengujian selanjutnya adalah konsistensi model. Dilihat dari nilai $A R$ (1) tolak $H_{0} \quad\left(H_{0}:\right.$ no autocorrelation) dan $A R$ (2) tidak tolak $\mathrm{H}_{0}\left(\mathrm{H}_{0:}\right.$ no autocorrelation $)$. Hal tersebut telah membuktikan bahwa hasil estimasi telah konsisten.

Berdasarkan hasil estimasi menunjukkan bahwa dengan pendekatan AB-GMM lag $Y_{i t-1}$ memiliki nilai koefisien yang positif. Nilai koefisien lag $Y_{i t-1}$ sebesar 0.9928 merupakan nilai dari $(1+\beta)$, sehingga $\beta$ bernilai negatif $(-0.0072)$ yang berarti bahwa telah terjadi konvergensi kondisional $(\beta)$ di negara ASEAN Plus Three dengan tingkat konvergensi sebesar $0.72 \%$. Sedangkan waktu yang dibutuhkan untuk mengeliminasi $50 \%$ kesenjangan adalah 95 tahun dengan asumsi ceteris paribus.

Hasil analisis dari variabel gross fixed capital formation (investasi tetap domestik) menunjukkan pengaruh positif dan signifikan pada taraf nyata $1 \%$. Hasil estimasi menunjukkan bahwa peningkatan investasi tetap domestik dapat meningkatkan pertumbuhan ekonomi di ASEAN Plus Three. Penelitian dari Karagiannis (2007) yang menyatakan bahwa di negara Eropa yang didominasi oleh negara maju memiliki hubungan positif dan signifikan antara investasi tetap domestik dan pertumbuhan ekonomi. Selain itu, Hussin dan Saidin (2012) menyatakan bahwa investasi tetap domestik di Malaysia, Indonesia, Thailand dan Filipina juga memiliki hubungan yang positif dan signifikan terhadap pertumbuhan ekonomi. Hasil estimasi sesuai dengan hipotesis yang diajukan, bahwa investasi tetap 
domestik berdampak positif terhadap pertumbuhaan ekonomi.

Berdasarkan Tabel 1 kolom 5 telah memenuhi kriteria model panel dinamis terbaik. Hal tersebut dibuktikan dengan hasil estimasi pada lag $Y_{i t-1}$ sebesar (0.9890) yang berada diantara hasil estimasi pada FEM dan PLS adalah (0.9644-0.9894) yang menunjukkan bahwa hasil estimasi tidak bias. Uji Hansen digunakan untuk

Tabel 1 Hasil Estimasi Konvergensi Kondisional $(\beta)$ dengan Knowledge-Based Economy (KBE)

\begin{tabular}{|c|c|c|c|c|c|c|}
\hline \multirow{3}{*}{ Variabel } & \multicolumn{6}{|c|}{ Koefisien } \\
\hline & \multicolumn{3}{|c|}{ FEM } & \multicolumn{3}{|c|}{$A B-G M M$} \\
\hline & 1 & 2 & 3 & 4 & 5 & 6 \\
\hline Cons & $\begin{array}{l}-0.0389 \\
(0.934)\end{array}$ & $\begin{array}{l}-0.0467 \\
(0.922)\end{array}$ & $\begin{array}{l}0.5394 \\
(0.360)\end{array}$ & $\begin{array}{l}-0.0953 \\
(0.555)\end{array}$ & $\begin{array}{l}-0.3146 \\
(0.288)\end{array}$ & $\begin{array}{l}-0.3783 \\
(0.180)\end{array}$ \\
\hline $\ln Y_{i t-1}$ & $\begin{array}{l}0.9639 \text { *** } \\
(0.000)\end{array}$ & $\begin{array}{l}0.9644 * * * \\
(0.000)\end{array}$ & $\begin{array}{l}0.9427 * * * \\
(0.000)\end{array}$ & $\begin{array}{l}0.9928 * * * \\
(0.000)\end{array}$ & $\begin{array}{l}0.9890 * * * \\
(0.000)\end{array}$ & $\begin{array}{l}0.9917 \text { *** } \\
(0.000)\end{array}$ \\
\hline LnTrade & $\begin{array}{l}-0.0014 \\
(0.921)\end{array}$ & $\begin{array}{l}-0.0013 \\
(0.931)\end{array}$ & $\begin{array}{l}-0.0034 \\
(0.816)\end{array}$ & $\begin{array}{l}0.0026 \\
(0.255)\end{array}$ & $\begin{array}{l}0.0051 \\
(0.157)\end{array}$ & $\begin{array}{l}0.0055 \\
(0.166)\end{array}$ \\
\hline$G F C F$ & $\begin{array}{l}0.0004 \\
(0.604)\end{array}$ & $\begin{array}{l}-0.0004 \\
(0.616)\end{array}$ & $\begin{array}{l}-0.0006 \\
(0.469)\end{array}$ & $\begin{array}{l}0.0020 \text { *** } \\
(0.000)\end{array}$ & $\begin{array}{l}0.0008 \\
(0.318)\end{array}$ & $\begin{array}{l}0.0009 \\
(0.299)\end{array}$ \\
\hline GovC & $\begin{array}{l}-0.0003 \\
(0.838)\end{array}$ & $\begin{array}{l}0.0003 \\
(0.837)\end{array}$ & $\begin{array}{l}0.0006 \\
(0.747)\end{array}$ & $\begin{array}{l}-0.0004 \\
(0.424)\end{array}$ & $\begin{array}{l}-0.0001 \\
(0.957)\end{array}$ & $\begin{array}{l}-0.0002 \\
(0.846)\end{array}$ \\
\hline LnPOP & $\begin{array}{l}0.0942 \\
(0.442)\end{array}$ & $\begin{array}{l}0.0961 \\
(0.439)\end{array}$ & $\begin{array}{l}-0.0017 \\
(0.990)\end{array}$ & $\begin{array}{l}0.0318 \\
(0.450)\end{array}$ & $\begin{array}{l}0.0853 \\
(0.271)\end{array}$ & $\begin{array}{l}0.0981 \\
(0.184)\end{array}$ \\
\hline LnPaten & & $\begin{array}{l}-0.0007 \\
(0.916)\end{array}$ & $\begin{array}{l}-0.0019 \\
(0.769)\end{array}$ & & $\begin{array}{l}0.0045^{*} \\
(0.067)\end{array}$ & $\begin{array}{l}0.0048 * * \\
(0.032)\end{array}$ \\
\hline Iuser & & & $\begin{array}{l}0.0112 * \\
(0.093)\end{array}$ & & & $\begin{array}{l}-0.0048 \\
(0.253)\end{array}$ \\
\hline Obs & 130 & 130 & 130 & 130 & 130 & 130 \\
\hline$R^{2}$ & 0.9996 & 0.9995 & 0.9994 & & & \\
\hline \multicolumn{7}{|l|}{ Uji Abond } \\
\hline$A R(1)$ & & & & $0.030 * *$ & $0.030 * *$ & $0.029 * *$ \\
\hline$A R(2)$ & & & & 0.256 & 0.262 & 0.260 \\
\hline Uji Hansen J & & & & 1.000 & 1.000 & 1.000 \\
\hline
\end{tabular}

Keterangan:*) signifikasi pada taraf $10 \%, * *)$ signifikansi pada taraf $5 \%$,***) signifikansi pada taraf $1 \%$ dan angka dalam kurung menunjukkan $p$-value.

Sumber: Output Stata12 
Selain itu, hasil estimasi menunjukkan bahwa lag $Y_{i t-1}$ memiliki nilai koefisien yang positif sebesar 0.9890 dan signifikan pada taraf nyata 1\%. Pada pendekatan $A B-G M M$ nilai koefisien lag $Y_{i t-1}$ merupakan nilai dari $(1+\beta)$, sehingga $\beta$ bernilai negatif (0.011 ) yang berarti bahwa telah terjadi konvergensi kondisional $(\beta)$ di negara ASEAN Plus Three dengan tingkat konvergensi sebesar $1.1 \%$. Sedangkan waktu yang dibutuhkan untuk mengeliminasi 50\% kesenjangan adalah 62 tahun dengan asumsi ceteris paribus.

Berdasarkan Tabel 1 kolom 6 juga telah memenuhi kriteria model panel dinamis terbaik. Hal tersebut dibuktikan dengan hasil estimasi pada lag $Y_{i t-1}$ sebesar (0.9917) yang berada diantara hasil estimasi pada FEM dan PLS adalah (0.9427-0.9918) yang menunjukkan bahwa hasil estimasi tidak bias. Uji Hansen digunakan untuk mengukur tingkat validitas dari hasil estimasi menunjukkan bahwa hasil uji Hansen tidak tolak $H_{0}$ ( $H_{0}$ : valid). Pengujian yang terakhir adalah konsistensi. Dilihat dari nilai $A R$ (1) tolak $\mathrm{H}_{0}\left(\mathrm{H}_{0}\right.$ : no autocorrelation $)$ dan $A R$ (2) tidak tolak $H_{0} \quad\left(H_{0}:\right.$ no autocorrelation). Hal tersebut telah membuktikan bahwa hasil estimasi konsisten.

Hasil estimasi tersebut menggunakan dua indikator $K B E$, yaitu pengguna internet (internet user) dan paten. Hasil estimasi menunjukkan bahwa koefisien pada lag $Y_{i t-1}$ positif sebesar 0.9917 dan signifikan pada taraf nyata $1 \%$. Pada pendekatan $A B-G M M$ nilai koefisien $\operatorname{lag} Y_{i t-1}$ sebesar 0.9917 merupakan nilai dari $(1+\beta)$, sehingga $\beta$ bernilai negatif $(-0.0083)$ yang berarti bahwa telah terjadi konvergensi kondisional $(\beta)$ di negara ASEAN Plus Three dengan tingkat konvergensi sebesar $0.8 \%$. Sedangkan waktu yang dibutuhkan untuk mengeliminasi $50 \%$ kesenjangan adalah 83 tahun dengan asumsi ceteris paribus. Ternyata dari kedua indikator $K B E$ yang digunakan, hanya variabel paten yang memiliki pengaruh positif dan signifikan terhadap pertumbuhan ekonomi.

Perlindungan terhadap hak kekayaan intelektual (paten) memang sangatlah penting untuk menstimulus inovasi dan investasi serta peningkatan pertumbuhan ekonomi. Oleh karena itu, pada tahun 1997 diselenggarakan kesepakatan TRIPS. Persetujuan TRIPS merupakan kesepakatan internasional yang paling comprehensif, dan merupakan suatu perpaduan yang unik dari prinsip-prinsip dasar GATT (General Agreement on Tariff and Trade) mengenai national treatment dan most-favoured nation dengan ketentuan-ketentuan substantif dari kesepakatan-kesepakatan internasional bidang hak kekayaan intelektual, antara lain Paris Convention for the protection of industrial Property dan Berne Convention for the Protection of Literary and Artistic Works.

Selain itu, pada tahun 2007 telah diselenggarakan KTT ASEAN Plus Three ke-11 di negara Singapura, dibuat rancangan kerja ASEAN Plus Three Cooperation Work Plan (2007-2017). Dokumen tersebut memberikan panduan strategis sebagai arahan kerjasama ASEAN Plus Three dimasa depan. Dokumen tersebut telah menetapkan kebijakan yang diantaranya kebijakan dalam bidang hak kekayaan intelektual (paten).

Beberapa kebijakan dalam bidang hak kakayaan intelektual (paten) di ASEAN Plus Three diantaranya: Pertama, melakukan pertukaran pandangan, pengalaman dan informasi dalam penciptaan, pemanfaatan, perlindungan, komersialisasi dan penegakan hak kekayaan intelektual dan isu-isu terkait yang menjadi perhatian 
bersama. Kedua, menentukan tindakan yang tepat untuk memperkuat sistem IP (Intellectual Property) dan meningkatkan kesadaran publik yang lebih besar terhadap IP dan IPR (Intellectual Property Right) di bidang pendidikan dan industri, komersialisasi $I P$, pemanfaatan informasi $I P$, dan transfer teknologi, sesuai dengan ketentuan yang relevan di WTO (World Trade Organization) perjanjian TRIPS (Intellectual Property Rights).

Ketiga, mempromosikan harmonisasi hukum IP dan sistem, yang memungkinkan untuk meningkatkan perdagangan dan investasi di kawasan ini dan memfasilitasi pendaftaran hak kekayaan intelektual. Keempat, mempromosikan kegiatan koperasi untuk meningkatkan pengetahuan yang lebih luas dari pejabat pemerintah dan IP profesional sehingga mereka dapat berkontribusi untuk pertumbuhan bisnis dan pengembangan. Kelima, berupaya untuk mendorong kebijakan teknologi transfer pada bagian dari perusahaan multinasional yang beroperasi di wilayah tersebut.

Indonesia telah memiliki berbagai pengaturan hukum terhadap hak kekayaan intelektual (paten) yang dapat ditemukan pada Undang-Undang Nomor 19 Tahun 2002 tentang Hak Cipta, Undang-Undang Nomor 14 Tahun 2001 tentang Paten, UndangUndang Nomor 15 Tahun 2001 tentang Merek, Undang-Undang Nomor 29 Tahun 2000 tentang Varietas Tanaman, Undang-Undang Nomor 30 Tahun 2000 tentang Rahasia Dagang, UndangUndang Nomor 31 Tahun 2000 tentang Desain Industri, dan Undang-Undang Nomor 32 Tahun 2000 tentang Desain Tata Letak Sirkuit Terpadu.

Namun menurut Pusat Kebijakan Regional dan Bilateral Kementerian Keuangan RI (2012) meskipun telah dilakukan berbagai kesepakatan dan cakupan hukum mengenai hak kekayaan intelektual tetapi yang menyatakan bahwa dalam implementasinya masih sering terjadi perlanggaran. Bentuk perlanggaran yang ramai terjadi di Indonesia adalah pembajakan atau plagiarism. Selain itu, ketersediaan infrastruktur yang kurang memadai dan dayasaing teknologi yang rendah di Indonesia (World Economic Forum 2011) sebagai penyebab tingkat kecepatan konvergensi dengan $K B E$ menjadi rendah.

\section{Analisis Konvergensi ( $\sigma$ )}

Konvergensi

menggambarkan semakin berkurangnya kesenjangan pendapatan per kapita sepanjang waktu. Analisis konvergensi $(\sigma)$ merupakan analisis rutut waktu untuk mengamati terjadinya konvergensi atas variabel pengamatan dilakukan dengan perhitungan koefisien variasi (coefficient of variation).

Tabel 2 menunjukkan bahwa pada tahun 2001-2014 nilai koefisien variasi GDP riil per kapita cenderung mengalami penurunan. Nilai koefisien variasi yang menurun sebesar 1.0907 (2001) menjadi 1.0000 (2014) yang menunjukkan bahwa semakin kecil disparitas atau telah terjadi konvergensi ( $\sigma)$ GDP rill per kapita di ASEAN Plus Three. Hal ini telah sejalan dengan hasil estimasi sebelumnya dimana telah terjadi konvergensi kondisional $(\beta)$ dilihat dari nilai koefisien positif pada lag GDP per kapita.

Lain halnya dengan variabel perdagangan (trade) selama periode 2001-2014 yang berfluktuasi. Pada tahun 2001-2003 nilai koefisien variasi mengalami penurunan 5.19 (2001) menjadi 4.78 (2003). Sedangkan pada tahun 2004-2014 nilai koefisien variasi cenderung mengalami peningkatan 4.82 (2004) menjadi 5.45 (2014). Nilai koefisien variasi yang 
meningkat mengindikasikan bahwa disparitas semakin melebar atau telah terjadi divergensi $(\sigma)$ pada variabel perdagangan (trade) di ASEAN Plus Three. Keterbukaan ekonomi di ASEAN Plus Three berpotensi untuk memperluas pasar bagi negara yang

memiliki dayasaing produk yang tinggi, tetapi untuk negara yang memiliki dayasaing produk rendah dapat dijadikan sebagai target pasar untuk negara lain. Hal tersebut menjadi salah satu indikasi penyebab terjadinya disparitas yang semakin melebar. Tabel 2 Perkembangan Nilai Koefisien Variasi dengan Indikator Knowledge-Based Economy (KBE) Tahun 2001-2014

\begin{tabular}{cccccccc}
\hline Tahun & $\begin{array}{c}\text { GDP Riil } \\
\text { per Kapita }\end{array}$ & $\begin{array}{c}\text { Konsumsi } \\
\text { Pemerintah }\end{array}$ & GFCF & Trade & Populasi & Paten & $\begin{array}{c}\text { Pengguna } \\
\text { Internet }\end{array}$ \\
\hline 2001 & 1.09 & 1.34 & 1.43 & 5.19 & 2.14 & 1.23 & 1.45 \\
2002 & 1.08 & 1.36 & 1.45 & 4.95 & 2.13 & 1.29 & 1.41 \\
2003 & 1.07 & 1.40 & 1.47 & 4.78 & 2.13 & 1.28 & 1.38 \\
2004 & 1.06 & 1.42 & 1.52 & 4.82 & 2.13 & 1.29 & 1.35 \\
2005 & 1.06 & 1.46 & 1.58 & 5.02 & 2.12 & 1.31 & 1.30 \\
2006 & 1.05 & 1.54 & 1.63 & 4.95 & 2.12 & 1.35 & 1.27 \\
2007 & 1.05 & 1.57 & 1.66 & 4.97 & 2.12 & 1.35 & 1.25 \\
2008 & 1.03 & 1.63 & 1.77 & 5.02 & 2.11 & 1.35 & 1.23 \\
2009 & 1.02 & 1.74 & 1.85 & 5.02 & 2.11 & 1.36 & 1.21 \\
2010 & 1.02 & 1.77 & 1.90 & 5.09 & 2.11 & 1.42 & 1.15 \\
2011 & 1.02 & 1.79 & 1.95 & 5.17 & 2.11 & 1.45 & 1.13 \\
2012 & 1.01 & 1.81 & 2.00 & 5.24 & 2.10 & 1.45 & 1.11 \\
2013 & 1.01 & 1.84 & 2.01 & 5.35 & 2.10 & 1.43 & 1.11 \\
2014 & 1.00 & 1.87 & 2.03 & 5.45 & 2.10 & 1.43 & 1.09 \\
\hline Sumber
\end{tabular}

Sumber: World Development Indicators 2016 (diolah)

Mehmood dan Azim (2013) menyatakan bahwa variabel perdagangan (trade) memiliki pengaruh negatif dan signifikan terhadap pertumbuhan ekonomi di negara Asia. Sedangkan seperti yang kita ketahui bahwa negara Asia didominasi oleh negara berkembang. Haryati dan Hidayat (2014) menyatakan terjadi hubungan jangka panjang antara pertumbuhan ekonomi dan ekspor yang berpengaruh negatif di negara berkembang, lain halnya dengan negara maju seperti Malaysia, Jepang dan Korea Selatan yang memiliki hubungan jangka panjang antara pertumbuhan ekonomi dan ekspor yang berpengaruh positif.

Nilai koefisien variasi pada variabel investasi tetap domestik
(GFCF) dan konsumsi pemerintah cenderung mengalami peningkatan periode 2001-2014. Nilai koefisien variasi untuk variabel investasi tetap domestik sebesar 1.43 (2001) menjadi 2.03 (2014). Sedangkan nilai koefisien variasi variabel konsumsi pemerintah sebesar $1.34 \quad$ (2001) mengalami peningkatan menjadi 1.87 (2014). Hal tersebut mengindikasikan bahwa telah terjadi divergensi $(\sigma)$ atau semakin melebarnya disparitas pada variabel investasi tetap domestik dan konsumsi pemerintah di ASEAN Plus Three.

Berbeda dengan nilai koefisien variasi variabel investasi tetap domestik dan konsumsi pemerintah cenderung mengalami peningkatan, variabel populasi memiliki nilai koefisien variasi cenderung menurun pada periode 2001- 
2014. Nilai koefisien variasi untuk variabel populasi sebesar 2.14 (2001) menjadi 2.10 (2014). Hal tersebut mengindikasikan bahwa telah terjadi divergensi $(\sigma)$ atau semakin melebarnya disparitas pada variabel populasi.

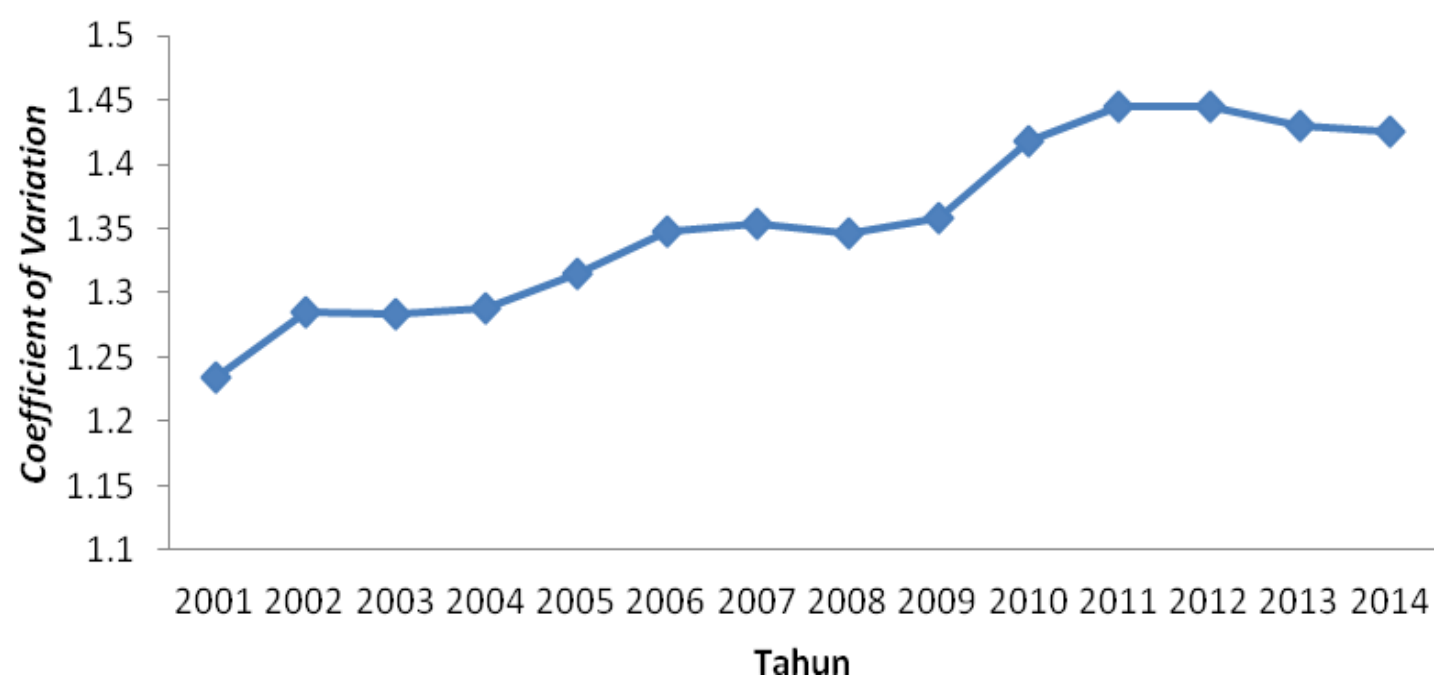

Sumber: World Development Indicators 2016 (diolah)

Gambar 2 Nilai Koefisien Variasi Paten

Nilai koefisien variasi pada indikator knowledge-based economy yang terdiri dari paten dan pengguna internet memiliki hasil estimasi yang berbeda. Gambar 2 menunjukkan bahwa paten memiliki nilai koefisien variasi yang cenderung meningkat 1.23 (2001) mejadi 1.43 (2014). Hal tersebut berarti bahwa telah terjadi divergensi $(\sigma)$ atau semakin melebarnya disparitas pada variabel paten di ASEAN Plus Three. Dibuktikan oleh data dari International Telecommunication Union (2016) yang menyatakan bahwa jumlah paten di negara maju jauh lebih tinggi dibandingkan dengan negara berkembang.

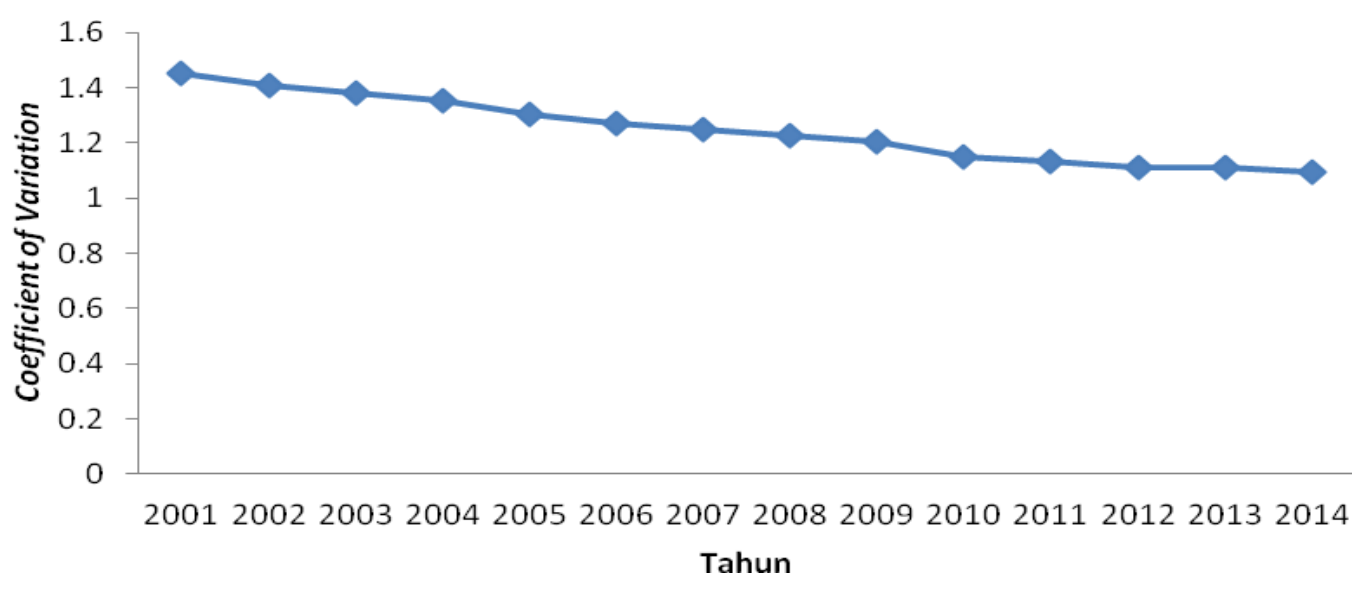

Sumber: International Telecommunication Union 2016 (diolah)

Gambar 3 Nilai Koefisien Variasi Pengguna Internet 
Sedangkan berdasarkan Gambar 3 menunjukkan bahwa nilai koefisien variasi dari variabel pengguna internet cenderung menurun periode 2001-2014. Nilai koefisien variasi sebesar 1.4515 (2001) mengalami penurunan hingga mencapai 1.0935 (2014). Hal tersebut mengindikasikan bahwa terjadi konvergensi $(\sigma)$ yang berarti bahwa disparitas untuk penggunaan internet di negara ASEAN Plus Three semakin kecil.

\section{SIMPULAN DAN SARAN}

\section{Simpulan}

Terjadi konvergensi kondisional $(\beta)$ dan konvergensi $(\sigma)$ untuk variabel $G D P$ riil per kapita di ASEAN Plus Three. Hasil estimasi menunjukkan bahwa nilai koefisien konvergensi kondisional $(\beta)$ sebesar 0.9928 dengan tingkat kecepatan konvergensi sebesar $0.72 \%$. Sedangkan hasil estimasi koefisien konvergensi dengan $K B E$ sebesar 0.9917, tingkat kecepatan konvergensi sebesar $0.8 \%$. Selain itu, Peran $K B E$ terhadap pertumbuhan ekonomi menunjukkan bahwa variabel paten berpengaruh positif dan signifikan terhadap pertumbuhan ekonomi. Namun, variabel paten memiliki nilai koefisien variasi yang cenderung meningkat. Hal tersebut berarti bahwa telah terjadi disparitas jumlah paten antarnegara di ASEAN Plus Three.

\section{Saran}

Berdasarkan hasil penelitian yang diperoleh, ada beberapa hal yang dapat disarankan, sebagai berikut:

1. Berdasarkan hasil dari penelitian konvergensi kondisional $(\beta)$ dengan knowledge-based economy diketahui bahwa variabel paten memberikan dampak positif dan signifikan terhadap pertumbuhan ekonomi, oleh karena itu seharusnya setiap negara yang tergabung dalam ASEAN Plus Three fokus terhadap pengembangan ilmu pengetahuan dan teknologi, sehingga dapat menciptakan inovasi. Hal tersebut dapat dilakukan dengan cara memberikan transfer teknologi atau ilmu pengetahuan dari negara maju ke negara berkembang.

2. Penelitian ini menggunakan jumlah pengamatan (negara) yang lebih banyak dibandingkan dengan periode waktunya, meskipun perlu kajian yang lebih lanjut tetapi hal tersebut diduga dapat mempengaruhi hasil estimasi model panel dinamis. Bagi penelitian selanjutnya, diharapkan dapat melakukan penelitian dengan jumlah pengamatan yang lebih besar dari jumlah waktunya, agar dapat menghasilkan hasil estimasi panel dinamis yang lebih baik.

\section{DAFTAR PUSTAKA}

Arsyad L. 1997. Ekonomi Pembangunan. Yogyakarta (ID); STIE YKPN.

ASEAN. 2007. ASEAN Work Plan 20072017. [internet]. [diunduh 2016 Agustus]. Tersedia pada: http : //www.mofa.go.jp/region/asiapaci /ASEAN/conference IASEAN3/plan0711.pdf.

Bhaduri A. 2007. Growth, Distribution and Innovation. New York : Routledge..

Chen F, Sun X. 2013. Analysis on the changes of convergence of regional economic growth in China: 1984-2010.

Coates D, Warwick K. 1999. The knowledge driven economy: 
analysis and background. In The Economics of the Knowledge Driven Economy, Papers presented at a conference jointly organised by the Department of Trade and Industry and the Centre for Economic Policy Research. (27).

Dekiawan H. 2014. Konvergensi Penerimaan dan Pengeluaran Pemerintah Provinsi di indonesia: Pendekatan data panel dinamis spasial. Buletin Ekonomi Moneter dan Perbankan. 17(1), 99-128.

Firdaus M, Yusop Z. 2009. Dynamic Analysis of Regional Convergence in Indonesia. International journal of economic and management. 3(1) :73-86.

Firdaus M. 2011. Aplikasi Ekonometrika untuk Data Panel. Bogor (ID):Penerbit IPB Press.

Haryati SN, Hidayat. 2014. Analisis Kausalitas antara Ekspor dan Pertumbuhan Ekonomi di ASEAN Plus Three. Jurnal Ekonomi dan Keuangan. 2(6).

Hussin F, Saidin N. 2012. Economic growth in $A S E A N-4$ countries: a panel data analysis. International Journal of Economics and Finance. 4(9): 119.

Ismail NW. 2008. Growth and Convergence in ASEAN: A Dynamic Panel Approach. International journal of economic and management. 2(1) 127-140. International Telecommunications Union. Pengguna internet [internet]. [diunduh 2016 Mei]. Tersedia pada:

http://www.itu.int/en/Pages/defaul t. aspx

Karagiannis S. 2007. The KnowledgeBased Economy, Convergence and Economic Growth: Evidence from the European Union. The
Journal of Economic Asymmetries. 4(2): 65-85.

Kementerian Luar Negeri RI. 2011. Ayo Kita Kenali ASEAN. [internet]. [diunduh 2016 Agustus]

Lall SV, Yilmaz S. 2001. Regional economic convergence: Do policy instruments make a difference?. The annals of regional science. 35(1): 153-166. .

Mehmood B, Azim P. 2013. Does ICT Participate in Economic Convergence among Asian Countries: Evidence from Dynamic Panel Data Model. Journal Informatica Economica. 17(2).

Michelis L, Neaime S. 2004. Income convergence in the Asia-Pacific Region. Journal of economic integration. 19(3):470-498

Powell WW, Snellman K. 2004. The knowledge economy. Annual review of sociology. 199-220.

Stiglitz JE. 1999. Global Public Goods. New York : Oxford University Press, Inc.

Tocan MC. 2012. Knowledge based economy assessment. Journal of Knowledge Management, Economics and Information Technology. 2(5).

[WDI] World Development Indicators. Data variabel ekonomi [internet]. [diunduh 2016 Mei]. Tersedia pada: http://worldbank.org/

Wibowo BA. 2012. Peran Perkembangan Industri Keuangan dalam Konvergensi Perekonomian di Negara ASEAN+5 Periode Tahun 2002-2012. [Skripsi]. Bogor : Institut Pertanian Bogor.

[WEF] World Economic Forum. 2011. [internet]. [diunduh 2016 Agustus]. Tersedia pada: https://www.weforum.org/events/ 
world-economic-forum-annualmeeting-2011/

Young AT, Higgins MJ, Levy D. 2008. Sigma convergence versus beta convergence: Evidence from US county-level data. Journal of Money, Credit and Banking. 40(5): 1083-1093. 